\title{
The Relationship Between Malnutrition and Tuberculosis (TB) At The Age Group More Than 18 Years Old In Indonesia (Analysis Of The Basic Health Research 2018)
}

\author{
Kristina L.Tobing ${ }^{1}$, Olwin Nainggolan ${ }^{1}$, Faika Rachmawati ${ }^{1}$, Helper Sahat $\mathbf{P}$ \\ Manalu ${ }^{1}$, Ratna Dilliana Sagala ${ }^{2}$, Ina Kusrini ${ }^{3},{ }^{1}$ Researcher at the Research and \\ Development Center for Public Health Efforts Ministry of Health Republic of Indonesia, \\ ${ }^{2}$ Epidemiolog at the Directorate General Disease Prevention and Control Ministry of \\ Health Republic of Indonesia, ${ }^{3}$ Researcher at the Research and Development Unit in \\ Magelang Ministry of Health Republic of Indonesia,
}

The study aimed to determine the relationship between nutritional status based on Body Mass Index (BMI) and Tuberculosis (TB) in the age group $>18$ years. This study further analyzes the 2018 Basic Health Research (Riskesdas 2018), a cross-sectional study conducted in all city districts in 34 provinces of Indonesia. Unit samples of this study are population-based in the age group $>18$ years. The determination of having had TB is if the respondent answered yes to the question: "Has a doctor ever been diagnosed with TB by a period of $\leq 1$ year". Nutritional status based on BMI value by calculating height per body weight. Nutritional status was classified as: underweight: $\mathrm{BMI}<18.5$; normal: $\mathrm{BMI} \geq 18.5-<25.0$; Overweight: $\mathrm{BMI} \geq 25.0-<27.0$; obesity: BMI $\geq 27.0$. The total sample was 624,562 . The number of TB sufferers $3,220(0.5 \%)$. The number of underweight respondents 62,456 (9.4\%), normal respondents 344,941 (55.2\%), overweight and obese respondents $221,021(35.4 \%)$. There is a relationship between nutritional status and TB after controlling for confounding variables such as gender, education, type of work, residence, DM risk factors, and smoking behavior. Underweight has a risk of 7.67 (CI 6.40-9.20) of getting TB compared to overweight/obesity, while normal weight has a risk of 2.55 (CI 2.18-2.98) of getting TB compared to overweight/ obesity after controlled confounding variables. Underweight people have 7.67 times the risk of getting TB, and normal weight has 2.55 times have the prevalence ratio getting TB than obese 
International Journal of Innovation, Creativity and Change. www.ijicc.net

Volume 15, Issue 9, 2021

people. The Additional food program for TB patients whose weight is thin in the age group $>18$ years.

Key words: Adult, Nutritional Status, Tuberculosis, Underweight

\section{INTRODUCTION}

Tuberculosis (TB) disease is the leading cause of death from infectious diseases and one of the top 10 causes of death. (World Health Organization, 2020) As many as 56\% of TB cases globally are in five countries: India, Indonesia, China, the Philippines, and Pakistan, Indonesia. (Mahendradhata et al., 2017). TB disease caused 1.4 million deaths in the world in 2019. (World Health Organization, 2020)

The incidence of tuberculosis has shown a decline in the past 20 years from 370 per 100,000 population in 2000 to 312 per 100,000 in 2019. However, if you look at the decrease in incidence compared to the two countries with the highest caseload, namely India and China, Indonesia has not been able to keep pace decline in these two countries. The decrease in the incidence rate per 100,000 population in Indonesia is $1 \%$ per year, which is smaller than the increase in population, which reaches $1.2 \%$ per year. It causes the absolute number of incidence estimates to tend to remain even higher. (Kemenkes, 2018)

Globally, it is estimated that there were as many as 10 million TB cases in 2019. However, this number has been slowly decreasing in recent times. Based on geographic location, the most TB cases in 2019 were in Southeast Asia (44\%), Africa (25\%) and the Western Pacific (18\%), and a small percentage in the Middle East (8.2\%), America (2,9\%) and Europe (2.5\%). There are eight countries with the number of cases two-thirds of the total global cases, namely India (26\%), Indonesia (8.5\%), China (8.4\%), Philippines (6\%), Pakistan (5.7\%), Nigeria (4.4\%), Bangladesh (3.6\%) and South Africa (3.6\%). From the list of 30 countries with a high TB case burden, the remaining 22 countries account for $21 \%$ of the global number of cases. Based on the World Health Organization (WHO) published in the Global TB Report 2020, the indicators used in achieving the goal of "End the Global TB epidemic" are the number of deaths due to TB per year, the incidence rate per year, and the percentage of households that bear TB treatment costs. (World Health Organization, 2020)

In Indonesia, most TB sufferers are in the productive age group, namely the age group 15-54 years, $56 \%$ of 21,320 cases.(Kemenkes RI, 2018b) Based on gender, the number of new TB cases in 2017 in males was 1.4 times greater than in females. Even based on a survey, the prevalence of tuberculosis in men is three times higher than in women (Kemenkes RI, 2018a)

The issue of nutritional status is important because improving nutrition is one of the efforts to prevent transmission and eradicate pulmonary tuberculosis. The poor nutritional status will 
increase the risk of pulmonary tuberculosis. On the other hand, pulmonary tuberculosis contributes to poor nutritional status because of the disease process that affects the immune system (Utomo \& Margawati, 2016). Gupta et al. on Kholis Ernawati et al. said malnutrition could also cause a decrease in body immunity, increasing susceptibility to infection. Generally, active TB reduces nutritional status, as reported in several studies conducted in Indonesia, India, England, and Japan. Albumin serum in malnourished TB patients is generally low. (Gupta Krishna Bihari, 1961). Nutritional status is one factor that influences TB incidence at age $\geq 15$ years in Indonesia(Rukmini \& Chatarina, 2011), (Pangaribuan et al.,2020). Other health problems that can significantly affect developing TB are HIV, malnutrition, diabetes mellitus, smoking, and other conditions that cause decreased endurance. One of the factors related to pulmonary TB patients' nutritional status is energy and protein adequacy.(Floyd et al., 2013).

The research results by Feby Paitung et.al., obtained from 22 TB patients with $77.8 \%$ suffering from underweight, only 22.2\% had normal BMI values (Patiung, Wongkar, \& Mandang, 2014). Tuberculosis causes or worsens pre-existing nutritional deficiencies by reducing appetite and increased catabolism. Supriyo's research showed that malnutrition had a 7,583 times greater risk of developing pulmonary tuberculosis than normal nutritional status. (Supriyono, Baequny, Hidayati, Hartono, \& Harnany, 2013). Malnutrition in a person will affect the strength of the immune system and the immunological response to disease. (Hardinsyah, Kusharto, Sulaeman, \& Alisjahbana, 2014)

Naga in Clarita Paladan Konde et.al, also said that pulmonary tuberculosis is most often found at productive age, namely at 15-50 years. At this age, the demographic transition occurs, which can lead to a higher life expectancy in the elderly. In the elderly more than 55 years, the immunological system decreases, making it very susceptible to various diseases. (Clarita Paladan Konde, 2020)

Tjandra Yoga Aditama in Ziska Herawaty, said that there are at least three factors that cause the high TB cases in Indonesia, namely, the relatively long TB treatment time (6-8 months), which causes TB sufferers to be difficult to recover because TB patients stop treatment (drop) after feeling healthy even though the treatment process has not been completed. (Herawaty \& Kompeten, 2018). In addition, the problem of TB is exacerbated by the increasing number of HIV / AIDS infections that are growing rapidly and the emergence of MDR (Multi Drugs Resistant) TB problems. Another problem is the presence of latent TB sufferers, namely the patient is not sick but due to decreased immune system so that TB disease will appear. John Crofton et al stated that the decrease in body resistance affects the body's ability to fight TB infection. Several factors that can reduce immunity include malnutrition, age, gender, toxic substances such as cigarette smoke and large amounts of alcohol consumption, poverty, and comorbidities such as HIV/AIDS, diabetes, leukemia, silicosis, etc. (Crofton, Horne, \& Miller, 2009). 
International Journal of Innovation, Creativity and Change. www.ijicc.net

Volume 15, Issue 9, 2021

The results of the Riskesdas 2018 showed that the prevalence of underweight nutritional status based on the BMI category in the adult population (age $>18$ years) was $9.3 \%$ from 624,563 . It means that there are still 58,084 people aged $>18$ years who have a malnutrition status. The prevalence of pulmonary TB in Indonesia is $0.42 \%$ from 1,017,290 (weighted N). It means that 4,273 people have been diagnosed with tuberculosis by a doctor in the last one-year survey for all age groups. (Kemenkes RI, 2018b).

Based on the availability of the Riskesdas 2018 data, a further analysis was carried out which aims to determine the relationship of nutritional status based on BMI with TB at agegroup > 18 years in Indonesia after controlling for confounding variables such as gender, education, type of work, place of residence, diabetes mellitus risk factors and smoking behavior.(Kemenkes RI, 2018b).

\section{MATERIALS AND METHODS}

Indonesia is a country that has a vast population. Based on National Development Department (Bappenas) projections, Indonesia's population in 2018 will reach 265,000,000, with $26.6 \%$ in the $0-14$ age group, $67.6 \%$ of the productive age $15-64$ years, and $5.8 \%$ the elderly ( $\geq 65$ years and over. Based on these data, the percentage of productive age is relatively high, so it is essential to stay healthy and productive (Bappenas, 2018)

The study further analyses the 2018 Basic Health Research (Riskesdas) data in all districts/cities in 34 provinces in Indonesia. The data is obtained from the National Institute of Health Research and Development (NIHRD) by submitting a data request proposal to the head of Badan Litbangkes. After being reviewed by the Scientific Commission and corrected according to the review team's input, the data provided by the Data Management of the Badan Litbangkes.(Kemenkes RI, 2018b)

The study design was a cross-sectional study with a population of all individuals aged $>18$ years. The study sample was $>18$ years old and carried out the height and weight measurements and answered questions about the history of whether a doctor had been diagnosed with TB in the last one-year period. The sampling method for Riskesdas 2018 uses a multi-stage cluster technique. Before data analysis, weighting was carried so that the results of the research could describe the population. Furthermore, individual data includes the history of TB disease in the last year, nutritional status, age, sex, education, marital status, occupational smoking behavior, history of diabetes mellitus disease, and merging with data at the household level, namely the region.

Determination of TB exposure in Riskesdas 2018 based on bacteriological confirmation and seeing clinical symptoms(Kemenkes RI, 2018b) and the individual Riskesdas questionnaire answers. (Block A. Infectious Diseases (Code A05-A011). The dependent variable is the 
International Journal of Innovation, Creativity and Change. www.ijicc.net

Volume 15, Issue 9, 2021

incidence of TB based on bacteriological confirmation and seeing clinical symptoms. Respondents diagnosed with TB by a doctor during that period included in the group who had had TB. If they had never been diagnosed with TB, they fit in the group of respondents who had never had TB.

Nutritional status indicators used for the age group> 18 years are based on anthropometric measurements of body weight $(\mathrm{BW})$ and height $(\mathrm{H})$, which are presented in the form of Body Mass Index (BMI). The BMI formula is: BW $(\mathrm{kg})$ divide to $\mathrm{H}(\mathrm{m} 2)$. BMI limits used to assess nutritional status $>18$ years of age are as follows: underweight (BMI $<18.5$ ), normal (BMI $\geq$ $18.5-<25.0$ ), overweight (BMI $\geq 25.0-<27.0)$ and obesity (BMI $\geq 27.0$ ). (Kemenkes RI, 2018b)

Age is determined based on the Respondent's length of life, calculated from the date, month, and year of birth to the last birthday. The ages are grouped into two: the age group 19-54 years and $\geq 55$ years. The education level of the Respondent is the last education that the Respondent completes, is categorized into four, namely: Diploma/Academy/Open University/University ("S1/S2/S3") as university degree, Senior High School ("SMU/MA/SMK/Paket C group"), Junior High School ("SMP/SMPK/MTs/Paket B/Pesantren") and Primary/Elementary School ("SD/MI/Paket A"). Respondent's type of work status consists of: unemployed, school, civil servant/military/police/BUMN/BUMD, private employees, entrepreneurs, farmers, farm laborers, fishers, laborers, drivers, household helpers, and others. In this case, the work type classification will be divided into two groups: working and non-working groups, including schools.

Smoking is defined as a habit carried out by respondents in terms of smoking cigarettes divided into never smoking at all and ever smoking but who have quit and still smoking. diabetes mellitus disease is a chronic metabolic disorder caused by the pancreas not producing enough insulin, which regulates blood sugar levels. Determination of diabetes mellitus based on examination of blood sugar and history of diabetes mellitus. In this study, the determination of diabetes mellitus or not was based on the Respondent's answer to the question of whether he was diagnosed with diabetes/ diabetes mellitus by a doctor. (Utomo \& Margawati, 2016). An overview of the distribution and frequency and the characteristics of the research data are presented in a frequency distribution table in the form of proportions. Variables with a numerical scale are made categorical. The variables that will be changed are age, education level, employment status, smoking, and diabetes mellitus.

The analysis in this study uses a conceptual framework of a risk factor model approach in which nutritional status is the main independent variable and TB status is the dependent variable. In contrast, the sociodemographic variables and smoking behavior, and diabetes mellitus history were treated as confounding variables. Multiple logistic regression analysis was used to assess the relationship between the main independent variable, nutritional status, and the dependent 
variable, namely $\mathrm{TB}$ status. The amount of $\mathrm{N}$ generated using analysis of complex samples is called the number of weighted $\mathrm{N}$. The function of weighting is to equalize the opportunities resulting from sampling in Riskesdas 2018 instead of Simple Random Sampling (SRS), and the number of weighted $\mathrm{N}$ keeps the number of samples that have been weighted equally to the number of samples in the survey.

Statistical analysis was performed using SPSS 15 software. A suitable analysis is a complex sample analysis. Complex sample analysis was performed by including the weighting variable, Primary Sampling Unit (PSU), and strata. The variables analyzed were: sociodemographic (age, education, occupation, gender, marital status, residence) and risk factor variables (nutritional status, smoking, and diabetes mellitus). An overview of the distribution and frequency and the characteristics of the research data are presented in a frequency distribution table in the form of proportions. Variables with a numerical scale are made categorical. The variables that were changed were age, education level, employment status, smoking, and diabetes mellitus. Selection of variables in this study using simple logistic regression analysis with $\alpha=0.25$. Furthermore, multivariate analysis carried out using multiple logistic regression. Variables were included in the final model if the univariate analysis was $\mathrm{p}<0.25$ or if the variables were clinically important-multivariate analysis steps..(Ogston, Lemeshow, Hosmer, Klar, \& Lwanga, 1991).

There are limitations to this study, including the status of TB in the 2018 Riskesdas respondents, which was not confirmed with a diagnostic examination, but only in the form of questions to the Respondent whether they had been diagnosed with pulmonary TB by a doctor, nurse or midwife in the last one year. The data collected used a cross-sectional research design, making it difficult to determine the cause and effect because risk and effect data collection was carried out simultaneously. As a result, it cannot be determined whether malnutrition status causes TB or vice versa TB causes malnutrition status.

\section{RESULTS}

The total number of respondents aged $>18$ years was 624,562 people. Most of the respondents were aged 19-54 years (79.2\%), educated in elementary school (43.0\%), live in urban areas (55.4\%), married/living together $(74.7 \%)$, and workers $(69.1 \%)$. Based on the risk factors for $\mathrm{TB}$, most respondents were smokers $(65.7 \%)$, and a small proportion (2.2\%) suffered from diabetes. The nutritional status of respondents, mostly $55.2 \%$, has normal weight, but there is still 9.4\% with underweight nutrition. The number of respondents who suffered from TB or a doctor diagnosed in the past year was 3,220 people or $0.5 \%$ (table 1 ). 
International Journal of Innovation, Creativity and Change. www.ijicc.net

Volume 15, Issue 9, 2021

Tabel 1. Distribution of Respondents Based on Characteristics and Risk Factors (Riskesdas 2018 data analysis)

\begin{tabular}{|c|c|c|c|c|}
\hline \multicolumn{2}{|c|}{ Variables } & N (Weighted) & $\%$ & $95 \% \mathrm{CI}$ \\
\hline \multicolumn{5}{|l|}{ Character } \\
\hline \multirow[t]{2}{*}{ Age } & 19-54 years & 494,687 & 79.2 & $79.0-79.4$ \\
\hline & $\geq 55$ years & 129,875 & 20.8 & $20.6-21.0$ \\
\hline \multirow[t]{2}{*}{ Sex } & Female & 308,940 & 49.5 & $49.4-49.6$ \\
\hline & Male & 315,622 & 50.5 & $50.4-50.6$ \\
\hline \multirow[t]{4}{*}{ Level of education } & University & 59,392 & 9.5 & $9.3-9.7$ \\
\hline & Senior High School & 186,700 & 29.9 & $29.6-30.1$ \\
\hline & Junior High School & 109,725 & 17.6 & $17.4-17.7$ \\
\hline & Elementary School & 624,563 & 43.0 & $42.7-43.3$ \\
\hline \multirow[t]{2}{*}{ Marital Status } & No married/divorced & 157,773 & 25.3 & $25.1-25.5$ \\
\hline & $\begin{array}{l}\text { Married/living } \\
\text { together }\end{array}$ & 466,789 & 74.7 & $74.5-74.9$ \\
\hline \multirow[t]{2}{*}{ Type of Work } & Does not work & 192,969 & 30.9 & $30.7-31.1$ \\
\hline & Work & 431,593 & 69.1 & $68.9-69.3$ \\
\hline \multirow[t]{2}{*}{ Place of Residence } & Village & 278,673 & 44.6 & 44.4-44.9 \\
\hline & Urban & 345,889 & 55.4 & $55.1-55.6$ \\
\hline \multicolumn{5}{|l|}{ Risk Factor } \\
\hline \multirow[t]{3}{*}{ Smoke } & No & 213,957 & 34.3 & $34.1-34.4$ \\
\hline & Yes & 410,605 & 65.7 & $65.6-65.9$ \\
\hline & No & 610,801 & 97.8 & $97.7-97.8$ \\
\hline \multirow[t]{2}{*}{ Diabetes Mellitus } & Yes & 13,761 & 2.2 & $2.2-2.3$ \\
\hline & No & 213,957 & 34.3 & $34.1-34.4$ \\
\hline \multirow[t]{3}{*}{ Nutritional Status } & $\begin{array}{l}\text { Overweight } \\
\text { obesity }\end{array}$ & 221,021 & 35.4 & $35.2-35.6$ \\
\hline & Normal & 344,941 & 55.2 & $55.0-55.4$ \\
\hline & Underweight & 62,456 & 9.4 & $9.3-9.5$ \\
\hline \multirow[t]{2}{*}{ Tuberculosis } & No & 621,342 & 99.5 & $99.5-99.5$ \\
\hline & Yes & 3,220 & 0.5 & $0.5-0.5$ \\
\hline
\end{tabular}

The bivariate analysis results showed that $99 \%$ of respondents with nutritional status of obesity and normal weight did not suffer from TB. In comparison, $1.6 \%$ of the 58,599 underweight respondents suffered or were diagnosed with TB last year. The percentage of the age group 1954 years suffering from TB more than those aged $\geq 55$ years, and the percentage of men who suffer from TB is slightly more than women. Respondents with primary education have more TB than those with higher education. The number of TB sufferers was more common among married respondents, but as a percentage, there was no difference between those who were married and those who were not. It is also happening to respondents who work that suffer more 
International Journal of Innovation, Creativity and Change. www.ijicc.net

Volume 15, Issue 9, 2021

TB than those who do not work. There are $0.5 \%$ of the 431,593 respondents who work suffer from TB.

Meanwhile, $0.6 \%$ of the 192,968 unemployed respondents suffer from TB. Respondents living in cities were slightly more likely to suffer from TB than those in villages. Respondents who live in cities, $0.5 \%$ of the 345,889 , suffer from TB. Smoker respondents are more affected by TB than those who do not smoke. As much as $0.6 \%$ of the 410,605 smoker respondents are affected by TB. The number of diabetic respondents is less affected by TB, which is $1.9 \%$ of 13,761. (table 2)

Tabel 2: Cross Tabulation of TB Incidence with Sociodemographic Characteristics and Nutritional Status in the Age Group >18 Years in Indonesia (Riskesdas 2018 Data Analysis)

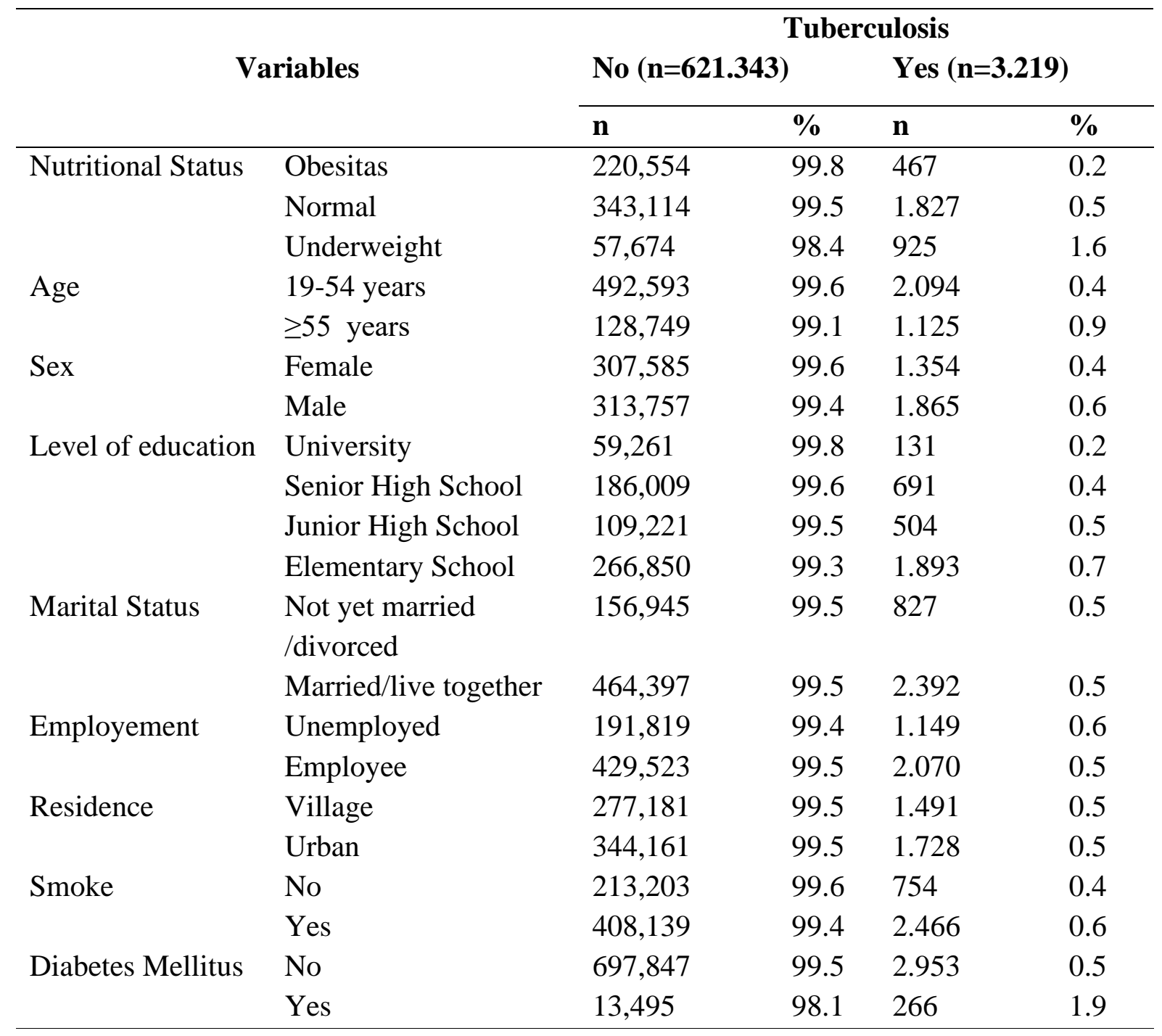


The multivariate analysis results obtained that almost all variables included in the analysis had a significant $\mathrm{p}$-value except for marital status; thus, such variable was excluded because the pvalue was $>0.05$. Other variables were entered into the subsequent analysis stage because the p-value was $<0.25$. The Nagelkerke $R$ Square value is 0.072 , which indicates that the independent variable, in this case, is the nutritional status which can explain the dependent variable (TB incidence) of 0.072 or $7.2 \%$. There are $100 \%-7.2 \%=92.8 \%$ other factors outside a research model that explains TB incidence.

Respondents who have underweight nutritional have a 7.67 risk of suffering from tuberculosis than those who are obese. Meanwhile, those with normal nutritional status have a 2.55 times more risk of contracting TB than those with overweight nutritional status. Respondents aged $\geq 55$ years have a 1.15 times risk of getting TB than those aged 18-54.

Malse have 2.44 times the risk of contracting TB than women. Elementary school is 3.17 times more likely to get TB than high school education and above. There was no significant difference between married and unmarried getting TB. People who live in cities have 1.13 times the risk of getting TB than those who live in villages. Smokers are 3.34 times more likely to get TB than non smokers. Diabetes Mellitus sufferers have a 3.96 times chance of getting TB than non- Diabetes Mellitus (table 3). 
International Journal of Innovation, Creativity and Change. www.ijicc.net

Volume 15, Issue 9, 2021

Tabel 3: Multivariate Analysis of The Relationship Between Nutritional Status (Based on BMI) in adults (> 18 years) and The Incidence of TB in Indonesia

(Riskesdas 2018 Data Analysis)

\begin{tabular}{|c|c|c|c|c|}
\hline \multirow[t]{2}{*}{ Variabel } & $\begin{array}{l}\text { OR Crude } \\
(95 \% \text { CI })\end{array}$ & $\begin{array}{l}\mathbf{P} \\
\text { value }\end{array}$ & $\begin{array}{l}\text { OR Adjusted } \\
\text { (95\% CI })\end{array}$ & P value \\
\hline & \multicolumn{2}{|c|}{ Early Model } & \multicolumn{2}{|l|}{ Final Model } \\
\hline \multicolumn{5}{|l|}{ Nutrition Status } \\
\hline Over Weight/Obesitas & Ref & 0,00 & Ref & 0,00 \\
\hline Normal & $2,51(2,16-2,93)$ & & $2,55(2,18-2,98)$ & \\
\hline Underweight & $7,57(6,38-8,99)$ & & $7,67(6,40-9,20)$ & \\
\hline \multicolumn{5}{|l|}{ Age } \\
\hline 19-54 years & Ref & 0,00 & Ref & 0,04 \\
\hline$\geq 55$ years & $2,06(1,84-2,30)$ & & $1,15(1,00-1,32)$ & \\
\hline \multicolumn{5}{|l|}{ Sex } \\
\hline Female & Reff & 0,00 & Ref & 0,00 \\
\hline Male & $1,35(1,21-1,50)$ & & $2,44(2,12-2,80)$ & \\
\hline \multicolumn{5}{|l|}{ Level of Education } \\
\hline University & Reff & & Ref & 0,00 \\
\hline Senior High School & $1,68(1,27-2,22)$ & 0,00 & $1,68(1,26-2,23$ & \\
\hline Junior High School & $2,09(1,55-2,80)$ & & $2,36(1,75-3,18)$ & \\
\hline Elementary school & $3,21(2,47-4,17)$ & & $3,17(2,41-4,16)$ & \\
\hline \multicolumn{5}{|l|}{ Married Status } \\
\hline $\begin{array}{l}\text { Not yet married } \\
\text { /divorced }\end{array}$ & Ref & 0,71 & Ref & \\
\hline Married/live together & $0,98(0,87-1,10)$ & & - & \\
\hline \multicolumn{5}{|l|}{ Employment Status } \\
\hline Unemployment & Ref & 0,00 & Ref & 0,04 \\
\hline Employee & $0,80(0,72-0,90)$ & & $0,84(0,74-0,96)$ & \\
\hline \multicolumn{5}{|l|}{ Residence } \\
\hline Village & Ref & 0,22 & Ref & 0,03 \\
\hline Urban & $0,93(0,84-1,04)$ & & $1,13(1,01-1,28)$ & \\
\hline \multicolumn{5}{|l|}{ Smoked } \\
\hline No & Ref & 0,00 & Ref & 0,00 \\
\hline Yes & $1,71(1,50-1,95)$ & & $3,34(2,84-3,91)$ & \\
\hline \multicolumn{5}{|l|}{ Diabetes Mellitus } \\
\hline No & Ref & 0,00 & Ref & 0,00 \\
\hline Yes & $4,07(3,39-4,89)$ & & $3,96(3,26-4,82)$ & \\
\hline
\end{tabular}


International Journal of Innovation, Creativity and Change. www.ijicc.net

Volume 15, Issue 9, 2021

\section{DISCUSSION}

The total number of TB incidents or respondents diagnosed with TB by a doctor in one year was 3,219 or $0.5 \%$ of 624,562 . There were $28.7 \%$ of 3,219 TB sufferers who had low nutritional status. Adult nutritional status is associated with tuberculosis after being controlled by confounding variables of age, sex, education, employment status, residence, smoking behavior, and diabetes mellitus. Respondents who had underweight nutritional status or BMI $<18.5$ had a 7.67 times risk of developing TB (CI 6.40-9.20) compared to those who had more weight/obesity after being controlled by confounding variables. Furthermore, people who have normal nutritional status or BMI $\geq 18.5-<25.0$ have a 2.55 times risk of developing TB $(95 \%$ CI 2.18-2.98) compared to those with more overweight/obesity or BMI $\geq 25$, controlled by confounding variables.

One of the factors that influence the incidence of pulmonary tuberculosis is the nutritional status. Comparison of weight and height describes the condition of a person's nutritional status. People who have an underweight body indicate that the person is malnourished. Another study showed that nutritional status is one of the factors associated with tuberculosis at $\geq 15$ years of age in Indonesia.(Rukmini \& Chatarina, 2011) (Pangaribuan et al., 2020) Likewise, in Rahmi's research, $63 \%$ of TB sufferers have an underweight nutritional status.(Surakhmi Oktavia, Rini, n.d.) The Kannan study showed that $90.54 \%$ of 74 TB patients were underweight.(Mirlohi, Ekrami, Shirali, Ghobeishavi, \& Pourmotahari, 2016) and 57 people (55.88\%) TB patients were underweight (BMI <18.5). (Hussien, Hussen, Seid, \& Hussen, 2019)

Research by Fariz Muaz (2014) stated that there was a relationship between nutritional status and the incidence of pulmonary tuberculosis. It can be understood that in general, malnutrition will weaken the immune system against disease, so that a person with poor nutritional status will be more likely to suffer from tuberculosis. (Muaz Fariz, 2014). Clarita Paladan's reseach found there found a relationship between nutritional status and pulmonary tuberculosis with $\mathrm{OR}=4.675$ with $\mathrm{CI}=1.755-12.453$ which means that the nutritional status is risk factors for pulmonary tuberculosis. (Clarita Paladan Konde, 2020)

Patients with pulmonary tuberculosis often experience decreased nutritional status to become malnourished if not balanced with a proper diet. The high prevalence of malnutrition in TB patients has been reported in other settings and has excess mortality. Poor nutritional status increases the risk of pulmonary tuberculosis. (Ernawati et al., 2018) In fact, pulmonary tuberculosis contributes to poor nutritional status because the disease process affects the immune system. Besides, the condition of health status is also related to recovery. Only $21.7 \%$ of patients with lean TB recovered, and 53.3\% did not recover. Meanwhile, $78.3 \%$ of TB patients with normal nutritional status recovered.(Izah, 2016). Therefore, nutritional intake is essential for TB patients, especially those underweight, to reduce the risk of death from TB. (Anurag \& Dash, 2009) 
In line with the results of Puspitasari's research, Mudigdo and Adriani (2017), which states that there is a dependence between nutritional status and treatment recovery suffered by pulmonary TB patients directly and based on calculations it is said to be significant. A good nutritional status makes it possible to recover. Nutritional status greatly affects the recovery or failure of pulmonary TB treatment because the nutritional status is categorized within normal limits to increase immunity so that a person can be resistant to pulmonary TB disease, in contrast to poor or poor nutritional status can complicate the healing process and can lead to the return of this pulmonary TB disease. (Ambar, 2017)

In this study, a large proportion (65\%) of TB patients were 19-54 years old. This shows the high number of TB cases in productive age. However, the analysis results showed that the age group $>55$ years had a 1.15 times more risk of contracting TB than those aged 19-54 years. This is almost the same as previous studies, where the age group $>55$ years has 1.7 times more risk of suffering from TB than those aged 15-34 years (Pangaribuan et al., 2020)

The results of this study showed that the number of men who had been diagnosed with TB by a doctor in one year was more (58\%) and had a 2.4 times risk of contracting TB than women. Research conducted at Pekanbaru Hospital found that $84 \%$ of TB patients aged 18-55 and 67\% were male. (Puspita, Christianto, \& Indra, 2013). In fact, based on the results of the 2013-2014 TB prevalence survey, the prevalence in men is three times higher than that of women. This is probably because men are more exposed to TB risk factors such as smoking. In this study the presentation of men who smoked higher than women. The tuberculosis prevalence survey results found that $68.5 \%$ of male participants smoked and only $3.7 \%$ of female participants who smoked. (Kemenkes RI, 2018a). In low- and middle-income countries, smoking is more common in males than females. It is very possible that behavioral factors play an important role in the occurrence of tuberculosis including smoking and alcohol consumption. (Plant et al., 2002). Riskesdas 2013 data shows that men who smoke every day or occasionally are $56.75 \%$, while women are only $1.9 \%$ (Kemenkes, 2013)

The level of education affects a person's knowledge. In this study, most $(58 \%$ of 3,219$) \mathrm{TB}$ patients had an SD/MI education. Participants with low education (SD / MI) had a 3.17 times risk of contracting TB than those with high education. According to Girsang M, there was a significant relationship between tuberculosis incidence in groups with low levels of education.(Girsang, 2010) Tuberculosis patients with an education level of fewer than nine years had a 3.3 times greater risk $(\mathrm{OR}=3.33)$ of contracting $\mathrm{TB}$ than those with more than nine years of education. (Handriyo \& SRW, 2017) Likewise, in other studies, it is known that a low level of education has a 3.94 times risk of contracting tuberculosis. (Oktavia, 2018).

The results of the 2013-2014 tuberculosis prevalence survey indicated a tendency that the higher the education, the TB prevalence rate was decreasing and vice versa. (Pangaribuan et al., 2020) 
International Journal of Innovation, Creativity and Change. www.ijicc.net

Volume 15, Issue 9, 2021

Smoking is a habit that harms health, especially the lungs. Smoking is a factor that can increase the risk of tuberculosis. In this study, most $(65 \%)$ or 408,139 respondents were smokers, and of this number, 2,466 (0.6\%) had TB in the past year. Smokers are 3.34 times more likely to develop TB than nonsmokers. Smoking here means people who have smoked but have quit or people who still smoke. Research in China obtained that people who have smoked 1.34 times got tuberculosis compared to those who never smoked.(Zhang et al., 2017) People who consume more than 20 cigarettes per day are more at risk of contracting tuberculosis.(Padrão, Oliveira, Felgueiras, Gaio, \& Duarte, 2018)

In this study, 13,495 who were > 18 years old had a doctor's Diabetes Mellitus diagnosis in the past year. Of these, $1.9 \%$ or 266 suffered from TB. The analysis results showed that Diabetes Mellitus patients had a 3.96 times more risk of developing TB than those who did not have diabetes. Another study revealed that people with type 2 diabetes mellitus had a 5.25 times risk of contracting tuberculosis.(Utomo \& Margawati, 2016)

\section{CONCLUSION}

Nutritional status based on BMI is associated with the occurrence of TB. People with underweight nutritional status (BMI <18.5) have a 7.67 times more risk of developing TB than obese nutritional status after controlling for confounding variables. The ministry of health has programmed the provision of additional food for TB sufferers, especially resistant TB. However, the program still needs to be improved in the community using education and additional food program provision for underweight TB sufferers.

\section{ACKNOLEDGMENT}

The author would like to thank Dra. Sarwo Handayani, M.Kes, has provided input on this article proposal. Thanks to the chair of the Scientific Commission for agreeing to carry out further analysis of the 2018 data based on Riskesdas.

\section{AUTHOR CONTRIBUTION}

The first author is the main contributor to the preparation of this article: KLT, especially on the concept of article content and its discussion, as well as contributors to ON members who contribute to data management and analysis. Other contributors: FR, HSPM, RDS and IK contributed to the discussion and review of the literature.

\section{CONFLICT OF INTEREST}

There is no conflict in this study. 
International Journal of Innovation, Creativity and Change. www.ijicc.net

Volume 15, Issue 9, 2021

\section{RESEARCH ETHICS}

The implementation of Riskesdas in 2018 has obtained ethical approval from the Health Research Ethics Commission (KEPK), the Health Research and Development Agency of the Ministry of Health of the Republic of Indonesia with number: LB.02.01/2/KE.267/2017 and then amended by number: LB.02.01/2/KE.024/2018.

\section{SOURCE OF FUNDS}

Funds for Riskesdas 2018 are sourced from the Center for Public Health Efforts for 2018. 
International Journal of Innovation, Creativity and Change. www.ijicc.net

Volume 15, Issue 9, 2021

\section{REFERENCES}

Ambar, P. (2017). Effects of Education, Nutrition Status, Treatment Compliance, Family Income, and Family Support, on the Cure of Tuberculosis in Mojokerto, East Java. 2, 95. https://doi.org/10.26911/theicph.2017.014

Anurag, M., \& Dash, D. (2009). Unraveling the potential of intrinsically disordered proteins as drug targets: Application to Mycobacterium tuberculosis. Molecular BioSystems, 5(12), 1752-1757. https://doi.org/10.1039/b905518p

Bappenas. (2018). Jumlah Penduduk Indonesia Mencapai 265 Juta Jiwa.

Clarita Paladan Konde, A. A. (2020). Hubungan Antara Umur, Status Gizi Dan Kepadatan Hunian Dengan Tuberkulosis Paru Di Puskesmas Tuminting Kota Manado. Kesmas, 9(1), 106-113.

Crofton, J., Horne, N., \& Miller, F. (2009). Crofton's Clinical Tuberculosis. In Design.

Ernawati, K., Ramdhagama, N. R., Ayu, L. A. P., Wilianto, M., Dwianti, V. T. H., \& Alawiyah, S. A. (2018). Perbedaan Status Gizi Penderita Tuberkulosis Paru antara Sebelum Pengobatan dan Saat Pengobatan Fase Lanjutan di Johar Baru, Jakarta Pusat. Majalah Kedokteran Bandung, 50(2), 74-78. https://doi.org/10.15395/mkb.v50n2.1292

Floyd, K., Anderson, L., Baddeley, A., Baena, I. G., Gebreselassie, N., Gilpin, C., ... Zignol, M. (2013). Global Tuberculosis Report 2013.

Girsang. (2010). Karakteristik Demografis Dan Hubungannya Dengan Penyakit Tuberkulosis Di Propinsi Jawa Tengah (Analisis Lanjut Riskesdas 2007). Media Penelitian Dan Pengembangan Kesehatan, XX(0), 40-45.

Gupta Krishna Bihari, D. (1961). Tuberculosis and nutrition. Deutsches Medizinisches Journal, 12, 145-149.

Handriyo, R. G., \& SRW, D. W. (2017). Determinan Sosial Sebagai Faktor Risiko Kejadian Tuberkulosis Paru Di Puskesmas Panjang. Jurnal Majority, 7(1), 1-5.

Hardinsyah, S., Kusharto, C. M., Sulaeman, A., \& Alisjahbana, B. (2014). Efek Pemberian Suplemen Sinbiotik Dan Zat Gizi Mikro (Vitamin a Dan Zinc) Terhadap Status Gizi Penderita Tbc Paru Orang Dewasa Yang Mengalami Kekurangan Energi Kronik. Gizi Indonesia, 34(1), 32-42. https://doi.org/10.36457/gizindo.v34i1.99

Herawaty, Z., \& Kompeten, J. (2018). Hubungan Status Nutrisi Terhadap Keberhasilan. $1(1), 20-25$.

Hussien, B., Hussen, M. M., Seid, A., \& Hussen, A. (2019). Nutritional deficiency and associated factors among new pulmonary tuberculosis patients of Bale Zone Hospitals, southeast Ethiopia. BMC Research Notes, 12(1), 1-13. https://doi.org/10.1186/s13104019-4786-y

Izah, N. L. (2016). HUBUNGAN ANTARA STATUS GIZI DENGAN KESEMBUHAN PADA PENDERITA TUBERKULOSIS PARU (pp. 45-46). pp. 45-46.

Kemenkes. (2013). Riset Kesehatan Dasar. https://doi.org/10.1126/science.127.3309.1275

Kemenkes. (2018). Inventory StudyTuberculocis in Indonesia 2016-2017. https://doi.org/978602-373-117 
International Journal of Innovation, Creativity and Change. www.ijicc.net

Volume 15, Issue 9, 2021

Kemenkes RI. (2018a). Infodatin Tuberkulosis. Kementerian Kesehatan RI, 1-8.

Kemenkes RI. (2018b). Laporan Hasil Riset Kesehatan Dasar (Riskesdas) Indonesia tahun 2018. Riset Kesehatan Dasar 2018, pp. 182-183.

Mahendradhata, Y., Trisnantoro, L., Listyadewi, S., Soewondo, P., MArthias, T., Harimurti, P., \& Prawira, J. (2017). The Republic of Indonesia Health System Review (Vol. 7).

Mirlohi, M.-S., Ekrami, A., Shirali, S., Ghobeishavi, M., \& Pourmotahari, F. (2016). Hematological and liver toxicity of anti-tuberculosis drugs. Electronic Physician, 8(9), 3005-3010. https://doi.org/10.19082/3005

Muaz Fariz. (2014). Kejadian Tuberkulosis Paru Basil Tahan Asam Positif Di Puskesmas Wilayah Kecamatan Serang Kota Serang Tahun 2014. Skripsi.

Ogston, S. A., Lemeshow, S., Hosmer, D. W., Klar, J., \& Lwanga, S. K. (1991). Adequacy of Sample Size in Health Studies. Biometrics, 47(1), 347. https://doi.org/10.2307/2532527

Oktavia. (2018). Pengaruh Kondisi Fisik Rumah Dengan Kejadian Tb Paru.

Padrão, E., Oliveira, O., Felgueiras, Ó., Gaio, A. R., \& Duarte, R. (2018). Tuberculosis and tobacco: Is there any epidemiological association? European Respiratory Journal, 51(1). https://doi.org/10.1183/13993003.02121-2017

Pangaribuan, L., Kristina, K., Perwitasari, D., Tejayanti, T., \& Lolong, D. B. (2020). FaktorFaktor yang Mempengaruhi Kejadian Tuberkulosis pada Umur 15 Tahun ke Atas di Indonesia. Buletin Penelitian Sistem Kesehatan, 23(1), 10-17. https://doi.org/10.22435/hsr.v23i1.2594

Patiung, F., Wongkar, M. C. P., \& Mandang, V. (2014). Hubungan Status Gizi Dengan Cd4 Pada Pasien Tb Paru. E-CliniC, 2(2). https://doi.org/10.35790/ecl.2.2.2014.5133

Plant, A. J., Watkins, R. E., Gushulak, B., O’Rourke, T., Jones, W., Streeton, J., \& Sang, D. (2002). Predictors of tuberculin reactivity among prospective Vietnamese migrants: The effect of smoking. Epidemiology and Infection, 128(1), 37-45. https://doi.org/10.1017/s0950268801006434

Puspita, E., Christianto, E., \& Indra, Y. (2013). Gambaran Status Gizi Pada Pasien Tuberkulosis Paru (Tb Paru) Yang Menjalani Rawat Jalan Di Rsud Arifin Achmad Pekanbaru. Journal of Chemical Information and Modeling, 53(9), 1689-1699.

Rukmini, \& Chatarina, U. (2011). Kejadian TB Paru Dewasa di Indonesia (Analisis Data Riset Kesehatan Dasar Tahun 2010). Buletin Penelitian Sistem Kesehatan, 14(4), 320331.

Supriyono, Baequny, A., Hidayati, S., Hartono, M., \& Harnany, A. S. (2013). Pengaruh perilaku dan status gizi terhadap kejadian TB paru di kota Pekalongan. Pena Medika Jurnal Kesehatan, 4(1), 8 .

Surakhmi Oktavia, Rini, S. (n.d.). Analisis Faktor Risiko Kejadian TB Paru Di wilayah Kerja Puskesmas Kertapati Palembang. Jurnal Ilmu Kesehatan Masyarakat, 7(2), 124-138. https://doi.org/https://doi.org/10.26553/jikm.2016.7.2.124-138

Utomo, R., \& Margawati, A. (2016). Hubungan Antara Status Diabetes Melitus Tipe 2 Dengan Status Tuberkulosis Paru Lesi Luas. Jurnal Kedokteran Diponegoro, 5(4), $1535-1544$. 
International Journal of Innovation, Creativity and Change. www.ijicc.net

Volume 15, Issue 9, 2021

World Health Organization. (2020). Global Tuberculosis Report 2020.

Zhang, H., Xin, H., Li, X., Li, H., Li, M., Lu, W., ... Gao, L. (2017). A dose-response relationship of smoking with tuberculosis infection: A cross-sectional study among 21008 rural residents in China. PLoS ONE, 12(4), 1-13.

https://doi.org/10.1371/journal.pone.0175183 